\author{
Hanna Veselovska Ганна Веселовська \\ professor, senior researcher, Modern Art Research Institute \\ of the National Academy of Arts of Ukraine \\ Аоктор мистецтвознавства, професор, головний науковий \\ співробітник Інституту проблем сучасного мистецтва \\ НАМ України
}

тем. / tel: +830442782845 e-mail: aveselovska@gmail.com orcid.org/0000-0002-4898-5000

\title{
Dead and Alive in the Digital Technologies Theatre
}

\author{
Киве і мертве \\ в театрі цифрових технологій
}

\begin{abstract}
As it was expected in the middle of the past century, digital and video technologies have fully penetrated the body of the modern theatre. Today using video serves a common director's method, both banally illustrative and conceptual, to stage many plays. With a wide spectrum of digital technologies in use by the theatre where actors are alive, questions arise to the co-existence and to the balance between living creatures and digital videos in the same space, to their interaction and conceptual directions.

Keywords: theatre, digital technologies, dead.
\end{abstract}

As it was widely expected in the middle of the past century, digital and video technologies have fully penetrated the body of the modern theatre. The change in the cultural orientation from a printed word to observation, video and websites has become a given and made a huge impact on the theatre as well. A theatrical product is now being likened to a video clip, with an instant turnover of a great amount of frame shots, selection of which often has a random nature but at times resembles a webpage with the function of hyperlinks.

In the beginning, video projection would simply replace painted decorations and space design. Later, it would only expand and enrich the spectrum of manipulations with space and time. In the high-technology synthesis of the screen and the live theatre, video has started to work towards making the theatre a more psychological and intellectual phenomenon, whilst computer graphics have become a common way to convey the state of soul and mind.

Today, the use of video is a trend of art at a good many theatres in Ukraine, conditioning the emergence of quite a number of interesting director's video solutions, both illustrative and conceptual. About the first Ukrainian spectacle to feature the use of video not as a background but a special way to show a hero's inner psychological and emotional state, was Kaspar, based on Peter Handke play, staged by French director Pierre-Jean Valentaine in a Kyiv theatre Koleso (A Wheel). In the grand scheme of things, this was just a foreword into the great incursion, if not acquisition, being made by video into theatre.

Among Ukrainian directors, Andriy Zholdak and Dmytro Bohomazov have been perhaps most active and innovative in using videos. They have given a new quality to the scenic product, by perceiving a virtual reality not as something that is placed nearby, but as the environment where a contemporary human being exists, the oxygen he or she breathes in.

Bohomazov-directed spectacles Roberto Zucco, by Bernard-Marie Koltes (2004), and Woman from the Past by Roland Schimmelpfennig (2007), are performed as syncretic actions, with what can be called a theatrilisation of video. The whisper of a human voice, the clapping of hands and bare feet are all dissolved in screen projections of thoughts, reminiscences and feelings, the virtual imitation of well-being and infernal black background. Mixed in one space are the other-sidedness, reality and virtual reality. By using videos, Bohomazov creates a timeless well-being, visualises the fact that a person may be found simultaneously in his or her own past, present and future, and will always stay where he or she used to be, even if long relocated here. Video graphics serve the main method to convey a hero's psychological state, his inner world, ideas, feelings, imaginations in the spectacle Rat Catcher written by Aleksander Grin (2010).

Andriy Zholdak had envisaged the theatre's dependence on video back in the 1990s and begun to consistently cram his performances with on-line videos, using them as the main aesthetic and structure-formative source. In a spectacle Life with an Idiot by Victor Yerofeev he injects something like a home video: the constant, tiring and deliberate filming of what goes on in the family that took a defective person for upbringing. Being filmed are sniffing and snoring, fami- 
ly quarrels, early-mourning dressing motions-almost anything that might be happening to a person during his or her physical existence. This is the primary feature of the spectacle in the course of which we can observe transformations of the idiot into the main family value and the human being into an idiot.

That was how theatre-tinged technologies and non-verbal means have become a fundamentally new way to depict deep inner states of mind, psychology in general. This attested to how much even in the art life a person of the post-industrial society may rely on high-tech findings. One spectacle that has aptly reflected such essential transformations of a human being through technical innovations is Hamlet. Babylon by director and set designer Dmytro Kostyuminskiy (2013). A huge screen that displays "interpretation of texts by authors from various historic epochs on the subject of Shakespeare's Hamlet, superimposed onto the contemporary issue of global multiculturalism", is turning into a space containing live actors. Changing colours and forms almost non-stop, this chimera becomes an effective visualisation of the virtual reality where both we and Shakespeare's characters exist. It is as if the flat surface resembling the magic mirror shows that we live in two worlds at once, with our bodies and souls ostensibly separated and in effect replacing each other from time to time.

Computer graphics by Dmytro Kostyuminskiy is synthesised with Oleksiy Retinskiy's music to create the atmosphere of an abstract meditative space that could be as attractive as the global network. Therefore, here comes a theatre that is like a black square: all and nothing, depth and plane-dimension of the symbol in which actors are designed to look like figures from computer games.

Usually, a virtual space created through video projections proves to be more typical for spectacles exploring the other-sidedness and transgression into a different reality. In the spectacle Onegin, based on the classical poem by Aleksander Pushkin and staged at the Pechersk Theatre in Kyiv, Dmitry Kostyuminsky through the fantasy video shows the famous dream of the main character (Tatyana's dream), her soul-searching, subconscious fears and wishes-everything that would be too scary to express in words. This director's solution proves not only visually effective and convincing but also suitable to actors. It basically allows them to avoid presenting non-reality in any false way, because they almost dissolve on the screen and are replaced by chimerical pictures, thereby completely loosing their identities and being manipulated in that virtual space like puppets.

Whereas in cases when actors tend to be dissolved and replaced by video in the depth of the stage there is no problem of coexistence and balanced relations between living creatures and digital videos, in some other cases this does become an issue. The coexistence of theatre actors with video normally appears most natural whenever a director draws distinction between something that comes alive - the bodyand dead, by projecting pictures on the screen where each is given clear functions.
A good example of the above point is the spectacle titled Vitalik-Ulysses, scenario written by contemporary Ukrainian playwright Vitaliy Chenskiy, directed by Maksim Holenko. This is a curios parody about the adventures of a young man from provincial town of Mariupol (the Donetsk region) in the capital Kyiv. Apart from the pragmatic goal to make a career and earn a good living, Vitalik sets out to do something noble as well. He looks to forge his own identity, to better understand his roots and where he comes from, eventually going down to what in reality his native land in the Donetsk region is today. A multi-functional video used in the spectacle projects a reality that is predominantly alien to the hero. When Vitalik tries to establish who he is and, off on a kind of Ulysses trip, thinks about various history themes, the screen behind his back shows pictures of pompous objects of the ancient civilisations.

When Vitalik ends up in Kyiv, the screen begins to run the pictures of a big chaotic city littered with rubbish. The video alienates even parts of our hero's body - the foot he injured while playing football is separately projected out on to the screen. Soon, the same picture is clogged with barbed wire, which to him is yet another incomprehensible and alien reality of the times when the former Ukrainian president with a criminal record, Victor Yanukovich, a native of Donetsk, held office. By the end of the spectacle, Vitalik again turns into Ulysses: computer graphics illustrate how he barely rows with virtual oars in a virtual sea, something that convincingly demonstrates the futility of his efforts to achieve the goal.

The theme of alien reality and territory of death is especially relevant and sensitive to the art community in Ukraine, which has been in the state of war for the last four years. Although developments in the East bring almost daily reports of soldiers and civilians killed along or near the frontline, the public opinion seems to be gradually getting used to war-inflicted deaths. As the protracted nature of that, war dilutes the sense of loss; on the people-to-people level the fact of numerous war victims starts to be seen as a norm, as if such deaths were natural and expected.

The feeling of irreversibility of the losses, the absurdity of military deaths and the striking fearlessness of human beings lost between life and death as well as their natural desire to survive - this is what the public may not be ready to talk about in full voice yet. However, this is what is being persistently addressed in the arts sphere, theatre in particular.

For Ukrainian theatre, with its long history of staging heroic and highly pathetic war dramas, to apply a different approach to the theme of death in war has been an extremely difficult task. In fact, when using video as a tool, directors of an older generation tend to underline in their performances, quite delicately and in the highly abstract way, the absurdity of deaths and irreversibility of losses and victims. For example, Vitaliy Malakhov in a spectacle Six Characters in Search of the Author by Luigi Pirandello, shows through a very nice symbolic picture how senseless the death of a girl in a swimming pool could be. In the other spectacle, his own take on Idiot, Vitaliy Pazunov talks about victims by using pictures of Jesus in a coffin. 
Unlike these directors-who are careful enough to look into the territory of death through the window of a video, directors of the middle-age and younger generations perceive the territories of dead and alive as fully comparable. Thus, in the case of Vitalik-Ulysses the territory of deathwhich is where shootings of the Maidan square protesters took place - is also a video frame. Witnessing gunshots being fired and projected onto the screen only through their sounds and flashes, the Maidan square is marked as the other reality of death through the natural fear of Vitalik who is afraid to take a rifle in his own hands.

Two premiers of the past year, Viy, staged by director Andriy Bakirov (the Chernihiv Theatre) and Take the Rubbish Out, Sasha, staged by director Tamara Trunova (The Kyiv Young Theatre) are spectacles where authors insist that exploring the territory of death is no less important for contemporary Ukraine than understanding problems of those alive. In both cases, the author of texts happens to be Ukrainian playwright Natalya Vorozhbit for whom the theme of historic memory is what forms the present and the future of the country. Into the plot of Gogol's Viy she weaves a story about the Holodomor, the Stalin-era repressions and the war in eastern Ukraine - the same alien reality which is associated with millions of victims and which Ukrainians have yet to free themselves of.

Appearing on the screen is the face of a dead Maiden by whose coffin a visiting Frenchman has to sit and chat the whole night long. Listening to confessions from the Frenchman who reads prayers to her on Skype, this girl is an embodiment of grief, accumulated and not experienced earlier by Ukrainians, which does not allow them to fully exist and express themselves today. She is the personification of people who are incapable of mastering their tragic past and therefore relive despair again and again. Only a prayer may bring salvation. In the final, the guy in an embroidered shirt is praying for all the victims of the past, while behind him on the screen there is a crowd of people of the past generations looming larger and larger. He recollects the war, famine, repressions, resettlement of peoples - a moment that is particularly sensitive to Crimean Tatar Adrij Bakirov. With each passing moment, there are more and more faces on the screen, but they decrease in size and eventually go away from us into the background. What emerges is such a necessary distance between those dead and alive who depend on each other and are interrelated by memories of the generations.

Take the Rubbish Out, Sasha is a text that is clearly divided into two parts: the first one being all about household routine unfolding prior to the infamous events in Donbas and the second one relating to when the war broke out and young men start getting killed. Former military servicemen Sasha dies from a heart attack even before the play starts, but when his relatives begin a ritual of mourningthat annoys him extremely, as he is also present on the stage. The spaces of death and life in this play are not only interdependent; they constantly intersect and interact. Sasha is being talked to as if he is alive, because those living are accustomed to him. At some point in the second part, however, there comes a moment when Sasha feels the need to intervene: he returns to life in order to join the war in Donbas and not let the young boys die.

There is no video that clearly delineates the territory of the dead in this play. Everybody acts and exists as if in real time: the living and dead characters do not stop arguing with each other. The territory of death - which is where the war rages on and is so relentless to the young and the best-is marked by running only one video in the prologue of the play. Being broadcast on the screen is the famous song performed by Marlene Dietrich about flowers that disappeared from the fields, about the dead soldiers.

\section{Веселовська $\Gamma$.}

Живе і мертве в театрі цифрових технологій

Анотація. Як і передбачалося, в середині минулого століття, цифрові та відеотехнології повноправно увійшли в тіло сучасного театру. Сьогодні використання відео є поширеним режисерським прийомом багатьох вистав, як банально ілюстративним, так і концептуальним. При великому спектрі використання цифрових технологій у театрі живих акторів, постають питання щодо співіснування та співвідносності живих фактур та цифрових відео в одному просторі, їхньої взаємодії та концептуальної спрямованості.

Ключові слова: театр, цифрові технології, мертве.

Веселовская А.

Живое и мертвое в театре цифровых техномогий

Аннотация. Как и преАполагалось, в среАине преАыдущего века, цифровые и видеотехнологии полноправно вошии в тело современного театра. Сегодня использование видео - частый режиссерский приём во многих представлениях, как банально имлюстративный, так и концептуальный. При большом спектре использования цифровых технологий в театре живых актеров, встают вопросы о сосуществовании и соотносимости живых фактур и цифровых видео в одном пространстве, о их взаимодействии и концептуальной направленности.

Кнючевые слова: театр, цифровые технологии, мертвое. 